\title{
ДЕЯКІ АСПЕКТИ РЕФОРМУВАННЯ ВИЩОЇ МЕДИЧНОЇ ОСВІТИ
}

\author{
Ю. М. Колесник, Ю. М. Нерянов, М. О. Авраменко, В. М. Компанієць, \\ Ю. Ф. Полковніков, О. А. Кремзер
}

Запорізький державний медичний університет

SOME ASPECTS OF HIGH MEDICAL EDUCATION REFORMING

\author{
Yu. M. Kolesnyk, Yu. M. Neryanov, M. O. Avramenko, V. M. Kompaniyets, \\ Yu. F. Polkovnikov, O. A. Kremzer \\ Zaporizhian State Medical University
}

\begin{abstract}
Введення реформ у медицині с витратним для державного бюджету, але вища освіта с одним 3 головних національних здобутків, і засоби, витрачені на їі розвиток, у довгостроковій перспективі обов'язково окупляться. Проведення реформи охорони здоров'я означас акцент на підготовці лікарів загальної практики i, в першу чергу, їх практичній підготовці. Головне завдання, яке необхідно вирішувати для поліпшення практичної підготовки лікарів у вітчизняній вищій медичній школі, - зміна парадигми цісї підготовки.
\end{abstract}

The introduction of reforms in medicine is cost-based for the state budget, but higher education is one of the major national achievements, so the resources, spent on its development in long term, will be repaid. Carrying out health care reform means emphasizing on training general practitioners and, primarily, their practical training. The shift of training paradigm is called to be the main task, that must be addressed for improvement practical training of physicians in national higher medical school.

Вступ. Система медичної освіти дісталася Україні в спадок від СРСР, що робила акцент на кількісних показниках підготовки лікарів. На сьогодні проведення реформ в Україні вимагає істотно інших підходів, $і$ це означає зосередження зусиль на підготовці лікарів загальної практики. Україна почала проведення реформи охорони здоров'я. Але деякі забули, що починати треба не тільки з лікарняного ліжка, але і зі студентської лави медичних вузів. Інакше гроші платників податків будуть витрачені даремно.

Основною проблемою вітчизняного освітнього процесу є недостатній рівень практичної підготовки випускників ВНЗ. Ця проблема гостро стоїть у всіх сферах діяльності суспільства, але особливо актуальна i життєво важлива для системи медичної освіти.

Не секрет, що підготовка лікарських кадрів в Україні в даний час не задовольняє ні суспільство, ні охорону здоров'я. Для вищої медичної школи України підвищення якості освіти це, перш за все, забезпечення прийнятного рівня клінічної підготовки студентів. Вдосконалення вищої медичної освіти дозволить більш обгрунтовано визначати потребу i пріоритети в підготовці медичних кадрів.

Основна частина. Викладачі медичних вузів постійно стикаються з наявністю певних проблем суб'єктивного і об'єктивного характеру, які в даний час надають як позитивний, так і негативний вплив на якість підготовки майбутніх лікарів. До них слід віднести інфантилізм і слабкий початковий рівень знань у студентів, що здобували середню освіту, особливо в малокомплектних сільських школах. У досить великої кількості студентів має місце недостатня мотивація до набуття навичок самостійної роботи, в першу чергу з пацієнтами, на що накладає свій відбиток значний об'єм навчальної інформації і зневажливе ставлення частини студентів до неклінічних дисциплін.

Окрім цього, на жаль все частіше зустрічаються ситуації, коли хворий не бажає присутності студентів при огляді. У ряді випадків і адміністрація лікувальної установи до певної міри намагається обмежити доступ студентів до хворих і документації (історій хвороби), мотивуючи свою позицію захистом персональних даних пацієнта. Така позиція керівників установ охорони здоров'я може бути пов'язана і з декларуванням останніми роками ситуації, коли ВМНЗ повинні будуть оплачувати перебування клінічних кафедр на базі лікувальних установ, які практично всі в даний час перейшли до розряду комунальних.

До причини недостатньої підготовки студентів, що зустрічається нечасто, слід віднести обмежену кількість якісних підручників, що повністю відпові- 
дають вимогам програм 3 дисциплін, збільшення інтенсивної інформаційної дії через систему електронних бібліотек, навчальних відеофільмів і ін. В цілому ж, викладання з використанням новітніх інформаційних технологій, на жаль, поки проводиться без оцінки їх негативної або позитивної дії на студентів.

Можливо, певною мірою проблеми сучасної медичної освіти криються в неоднозначності і плутанині основних понять, супроводжуючих процес навчання. Наприклад, у ВНЗ практично не вчать поведінки в неоднозначних ситуаціях, а на випускних іспитах деколи вимагають від студентів більше, ніж від атестованих фахівців. В умовах же навчання повинно бути навпаки: під час навчання необхідно створювати ситуації, що не завжди мають однозначне рішення, учити думати і міркувати, тобто застосовувати креативний підхід, а на іспиті - проводити атестацію на відповідність стандартної ситуації, тобто регламенту їі рішення в рамках того, що однаково сприймається всіма фахівцями, що входить у сферу єдиного інформаційного освітнього простору.

Головне завдання, яке необхідно вирішувати для поліпшення практичної підготовки лікарів у вітчизняній вищій медичній школі, - зміна парадигми цієї підготовки. В першу чергу треба міняти психологію і менталітет викладача, що складалися протягом десятиліть, і його роль у процесі навчання студентів.

Ще в давні часи існувало уявлення про такі методи навчання, які зараз визначаються як креативний і репродуктивний.

Відомий чеський педагог XVII ст. Я. Коменський говорив: “Слід було б починати навчання не із словесного тлумачення про речі, а з реального спостереження за ними. I лише після ознайомлення 3 самою річчю хай йде про неї мова, що з'ясовує справу більш всесторонньо... Якщо іноді немає в наявності речей, то можна замість них застосовувати копії або зображення, спеціально приготовані для навчання".

Цей вислів дуже добре ілюструє приклад впровадження в педагогічний процес ЗДМУ інноваційних технологій, а саме те, що у 2012 році університет став переможцем 5-го конкурсу проектів міжнародної програми “Tempus”. Проект фінансується Виконавчим агентством $з$ освіти, аудіовізуальних засобів і культури (ЕАСЕА) Європейського Союзу.

Підписано договір з одним з найвідоміших і найпопулярніших мовних центрів у світі (Каплан коледж, Ванкувер, Канада) на виконання наукових досліджень у напрямку “Створення міжрегіональної мережі національних центрів медичної освіти”, головним напрямом діяльності яких є впровадження проблемно- орієнтованого навчання із застосуванням віртуальних пацієнтів.

Освітня програма Свропейського Союзу підтримує модернізацію системи вищої освіти та створює простір для співпраці в країнах-партнерах ЄС через університетські проекти. Вона спрямована на добровільне наближення систем вищої освіти в країнахпартнерах до здобутків розвитку вищої освіти в країнах $\mathrm{CC}$.

Головним координатором проекту є Університет Святого Георга у Лондоні, наші партнери з проекту Медичний інститут Сумського державного університету, Медичний університет “Астана” (Казахстан), Карагандінський державний медичний університет (Казахстан), Салонікський університет ім. Арістотеля (Греція), Університет Нікосії(Кіпр), Медичний університет ім. Давида Твілдіані (Грузія), Державний університет Акакія Церетелі (Грузія).

Участь держав-партнерів проекту передбачає створення груп студентів, які будуть навчатися за програмою проблемно-орієнтованого навчання із застосуванням “віртуальних пацієнтів", розробленою Університетом Святого Георга у Лондоні.

Ми сподіваємося на отримання позитивного досвіду від участі у зазначеному проекті, який розрахований на 54 навчальних тижні, незважаючи на цілу низку питань методологічного характеру, необхідності внесення коректив до навчального плану 3 детальною індивідуалізацією для кожного студента, додаткового навантаження на студентів та викладачів, які задіяні в ньому.

Аналізуючи педагогічну літературу 3 методів навчання, можна зробити такі два висновки:

I. Метод навчання - це спосіб спільної діяльності студентів і викладача, направлений на досягнення цілей навчання.

II. Всілякі прийоми навчання (читання лекцій, проглядання відеофільмів, спостереження за роботою фахівців, вивчення наочної допомоги і препаратів, проведення навчального дослідження, вирішення ситуаційних завдань, участь у конференціях, семінарах, навчальні ігри і так далі) можна звести до двох принципово різних методів навчання: “ознайомлення 3 інформацією” і “виконання повчальних завдань”.

Отже, якщо в цілях навчання є завдання підсилити практичну підготовку, то це означає, що метод навчання “виконання повчальних завдань" - креативний, повинен переважати над методом “ознайомлення 3 інформацією” - репродуктивним. Мало того, необхідні спеціальні методики, сприяючі тому, щоб, виконуючи конкретне завдання, студент не тільки 
освоював алгоритм успішної професійної діяльності, але і вчився здобувати необхідну для іiі здійснення вірну інформацію.

Формування практичних умінь і навиків може здійснюватися тільки із застосуванням діяльнісного підходу в навчанні. Суть методик діяльнісного підходу в тому, щоб вчити діяльності, дій на основі “добування" знань і уміння їх застосовувати.

У зв'язку з цим, очевидним є те, що підходи до вдосконалення практичної підготовки в медичному ВНЗ через інтенсивні шляхи розвитку, на відміну від екстенсивних, найбільш продуктивні. У медичних навчальних закладах, у тому числі і в ЗДМУ, почали організовуватися так звані фантомні центри практичної підготовки.

Історично тренажерні технології виникли і отримали найбільший розвиток там, де помилки при навчанні на реальних об'єктах можуть призвести до надзвичайних наслідків, а їх усунення - до великих фінансових витрат: у військовій справі, ліквідації наслідків стихійних лих, в атомній енергетиці, авіації і космосі. Навчання на фантомах давно використовується на окремих кафедрах нашого університету. Але саме в умовах фантомного центру зміст навчання може бути направлений не тільки на освоєння окремих навиків, але і на міждисциплінарне навчання роботі в команді, вироблення безпечних форм професійної поведінки і навиків спілкування з пацієнтом. Для створення ефективних методик навчання на фантомах і тренажеpax, в результаті яких можуть бути сформовані і підтверджені певні професійні компетенції, необхідні додаткові цілеспрямовані зусилля викладачів і в методичному аспекті.

Це не означає, що для забезпечення високої якості практичної підготовки студентів медичних вузів їх навчання повинне бути сконцентроване тільки на освоєнні практичних навиків на фантомах і тренажерах. Цілком сучасними повинно стати посилення ролі дисциплін, що забезпечують успішну соціалізацію студентів ї̈х включення в трудові відносини; загальна комп'ютерна письменність; вільне володіння рідною мовою; професійна орієнтація і передпрофесійна підготовка; забезпечення знання випускниками вищої школи на рівні функціональної письменності, як мінімум однієї іноземної мови і ін.

Необхідне використання певних педагогічних технологій, що забезпечують спадкоємність системи формування, відпрацьовування і вдосконалення прак- тичних навиків і підготовку до виконання професійної діяльності на всіх етапах навчання медичного працівника. Це повинно підтримуватися системним розвитком зв' язків між професійною медичною освітою і сферою практичної охорони здоров'я, що неможливе без вдосконалення ефективної системи працевлаштування випускників медичних вузів, зокрема шляхом розвитку цільової контрактної підготовки. І в цьому напрямі нашим університетом вже здійснюється цільова підготовка студентів, навчання яких фінансують відповідні районні адміністрації не тільки Запорізької, але і кількох суміжних областей.

Усвідомлюємо, що введення реформ є витратним для державного бюджету, проте ще раз звертаємо увагу на те, що вища освіта є одним 3 головних національних здобутків, і засоби, витрачені на їі розвиток, ми переконані, в довгостроковій перспективі обов'язково окупляться.

Висновки: 1. Вдосконалення вищої медичної освіти дозволить білыш обгрунтовано визначати потребу і пріоритети в підготовці медичних кадрів.

2. У системі вищої медичної освіти існують проблеми суб'єктивного і об'єктивного характеру, які впливають на якість підготовки майбутніх лікарів.

3. Певна кількість студентів має недостатню мотивацію до отримання знань.

4. Викладання дисциплін з використанням новітніх інформаційних технологій нерідко проводиться без оцінки їх негативної або позитивної дії на студентів.

5. Необхідна зміна парадигми практичної підготовки лікарів.

6. Необхідне впровадження спеціальних методик, сприяючих тому, щоб студент не тільки освоював алгоритм успішної професійної діяльності, але і вчився здобувати необхідну для їіздійснення вірну інформацію.

7. Підходи до вдосконалення практичної підготовки у ВМНЗ через інтенсивні шляхи розвитку найбільш продуктивні.

8. Сучасним у навчальному процесі повинно стати посилення ролі дисциплін, що забезпечують успішну соціалізацію студентів і їх включення в трудові відносини.

9. Необхідно вдосконалювати систему використання педагогічних технологій, що забезпечують спадкоємність системи формування, відпрацьовування i вдосконалення практичних навиків і підготовку до виконання професійної діяльності на всіх етапах навчання медичного працівника. 


\section{Лiтература}

1. Богатирьова Р. В. Відкрита лекція Міністра охорони здоров'я, 25.02.2013 p.

2. Завдання вищої медичної освіти в контексті реформування галузі / Р. О. Моісеєнко, В. В. Вороненко, І. І. Фещенко [ та ін.] // Ваше здоров’я. -2011. - № 31 .

3. Суліма Є. Невідкладні завдання системи вищої освіти на новому етапі Болонського процесу / С. Суліма // Вища школа. -2010. - № 11. - С. 5-13.

4. Тимошенко О. Організація та управління якістю освіти: проблемні підходи / О. Тимошенко // Вища освіта України. - 2010. - № 1.-С. 60-66. 